\title{
Pedagogical Roles and Competencies of University Teachers Practicing in the E- Learning Environment
}
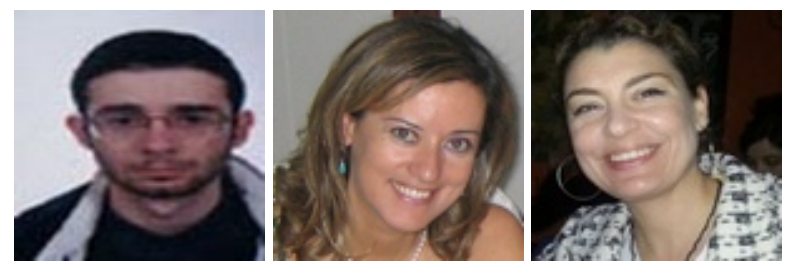

Pablo César Muñoz Carril ${ }^{1}$, Mercedes González Sanmamed², Nuria Hernández Sellés ${ }^{3}$ ${ }^{1}$ University of Santiago de Compostela, Spain, ${ }^{2}$ University of A Coruña, Spain, ${ }^{3}$ Centro Superior de Estudios La Salle, Spain

\section{Abstract}

Identifying the roles and competencies of faculty performing in virtual environments is crucial to higher education institutions in order to build a common frame for teaching and training initiatives. One of the goals of this study is to identify and systematize faculty's roles through a review of the most representative surveys. There has also been an effort to identify competencies associated to every role, with an emphasis on those of the pedagogical scope, by means of a focus group. Furthermore, a cross-sectional survey with 166 faculty participants has been conducted in order to identify faculty's level of proficiency on the pedagogical competencies and the interest in training programs. Teacher perceptions on both these aspects constitutes a relevant reference for the design of faculty training programs. Results reveal that content drafting is the aspect in which the subjects declare the highest level of proficiency as opposed to assessment. Faculty also appear to be willing to improve their training, being aware of the changes and requirements entailed by e-learning.

Keywords: Online teaching; online teacher roles; competencies; pedagogical competencies; interest in training 


\section{Introduction}

The integration of information and communication technologies (hereinafter ICT) in the education environment represents a complex process which depends on factors of a political, administrative, organizational, strategic, cultural, professional, and personal nature. These factors are particularly relevant for higher education because of the peculiarities of university institutions, regarding their management and structure, as well as their functioning and social projection.

In spite of the initial difficulties, the incorporation of ICT and e-learning into universities has experienced exponential growth, both in quantitative and qualitative terms (Bates \& Poole, 2003; Bates \& Sangrà, 2011; Barro \& Burillo, 2006; Bullen \& Janes, 2007; Carr-Chelleman, 2005; Hanna, 2002). As a consequence the teaching, research, management, and cultural extension patterns have been modified (Burbules \& Callister, 2000; Epper \& Bates, 2001; Lokken \& Womer, 2007; Sangrà \& González Sanmamed, 2004a).

As regards teaching, it is necessary to take into account that the design, development, and assessment of virtual education introduce particular features and require specific teaching tasks (Major, 2010; Spector, 2007). Therefore it is necessary to assess all the changes that teaching in virtual environments entail for the teacher, both at institutional and academic levels, and this from at least a dual perspective: clarifying the profile of the teacher who is going to be acting in the virtual classroom - which implies defining the roles and competencies of the teacher - and establishing the training required. This is the framework of the present survey.

\section{Literature Review}

Several authors have studied and made proposals regarding the roles and competencies of the teachers who participate in teaching programs in virtual environments. The surveys carried out on this subject are both of a theoretical and empirical nature and are meant to offer guidelines for the training, selection, and certification of online teachers.

The literature on the roles and competencies of the online teachers reveals two trends. Some authors understand that they are similar to those of a teacher in a face-to-face environment, since they both need to possess the knowledge necessary to effectively integrate ICT into teaching. Bautista, Borges, and Fores (2006) emphasize that although the competencies are similar, the roles to be assumed are different. In the international context, Goodyear, Salmon, Spector, Steeples, and Tickner (2001) recognize the similarities between face-to-face teaching and online teaching, but point out the differences in the way efficient teaching takes place.

Many other authors state that the prominence of ICT in online instruction modifies the elements of the teaching and learning process and conclude that there are teaching 
competencies that are specific to online teaching (Ardizzone \& Rivoltella, 2004; Belisle \& Linard, 1996; Espasa, Guasch, \& Álvarez, 2009; Laat, Lally, Lipponen, \& Simons, 2007; Muñoz Carril \& González Sanmamed, 2009; Yeung, 2003). For example, it is argued that teachers need to know how to use synchronous and asynchronous communication systems (Collison et el., 2000; Guasch, Álvarez, \& Espasa., 2010; Kearsley, 2000).

Bawane and Spector (2009) assert that the teachers performing online must assume a multidimensional role and are urged to integrate a range of different and numerous competencies. They also underline the fact that the teaching competencies required derive from the context in which the teaching is performed: the characteristics of the training program, the specific role of the teacher, and the financial, functional, and human resources available (e.g., the equipment of administrative staff, designers, technicians, etc.). Some researchers, such as Kreber and Kanuka (2006; quoted by Baran, Correia, \& Thompson, 2010), indicate that virtual education environments promote the exploration of new teaching approaches, derived from enhancing collaborative work or practices which incorporate social learning.

Based on these arguments, over the past few years there has been a certain interest in rigorously arranging and categorizing those roles and competencies that lead to an accurate definition of the online teacher profile.

On the other hand there have been international initiatives from several institutions that have drafted proposals of performance standards for online teaching, which specify the teaching competencies. Due to their particular relevance in this field, we may cite the proposals of the International Board of Standards for Training, Performance and Instruction (IBSTPI), of the International Society for Technology in Education (ISTE), or those from the European Institute for E-Learning (EIfEL). The work of these organizations has been considered to be a valuable reference for prestigious universities around the world.

Table 1 introduces an effort to offer a synthetic overview of the most representative surveys on the roles of the online teacher. This draft gathers the proposals of 14 authors regarding the roles of the online teacher. Subsequently Table 2 identifies the competencies associated with the various roles, with a special emphasis on those relative to the pedagogical scope.

In the preparation of these tables, different sources of information have been used: ERIC (Education Resources Information Centre); DOAJ (Directory of Open Access Journals); DIALNET (Hispanic scientific production portal); LATINDEX (Regional Cooperative Online Information System for Scholarly J ournals from Latin America, the Caribbean, Spain and Portugal), and ISOC (Higher Centre Portal for Scientific Investigation of Spain). 
The data compiled in Table 1 reveals the diversity of roles expected from an online teacher. In any case it is worth mentioning that in online environments teachers are not the only actors. Depending on the support offered to them as well as on the teaching context, they can interact with other professionals, such as instructional designers, graphic designers, technology experts, multimedia producers, media designers, managers, and so on (Guasch, Álvarez, \& Espasa, 2010; Marcelo, 2006). In this sense, Guasch, Álvarez, and Espasa (2010) stress the difficulties encountered by a teacher in developing such diverse competencies as those described in the proposals made by Williams (2003) or Egan and Akdere (2005). These authors defend collaboration between different professionals and propose three reference profiles within the elearning environment: the teacher, as an expert in the subject matter plans the methodology and the activities; the tutor, as an advisor and guide for the student; and the management staff, in charge of administrative and technological aspects.

In spite of the differences between the various proposals, some similarities can be identified. These commonalities appear between authors who share a certain historic moment and therefore share a vision regarding the competencies required for the online teacher. For example, the proposal made by Berge (1995) concurs with the proposal drafted by Wiesenberg and Hutton (1996), and - according to Baran, Correia, and Thompson (2010) - these roles were proposed when the e-learning practice was emerging and the main activities were designed around online discussions. However, the growing increase in new teaching environments, such as virtual worlds, metaverses, and other types of platforms, led Berge (2008) to change some parameters of his initial proposal, considering new approaches such as informal education, collaborative work, reflexive learning, and user generated content. Other proposals, such as those developed by Coppola et al. (2002) or Williams (2003), still focus mainly on the roles associated with communicative situations, though assuming the possibilities of asynchronous teaching as well as the different interactions that can take place between the teacher and the students, between the students, and between the teacher, the students, and the content.

On the other hand, coincidences arise from the fact that some authors build their proposals on those drafted by other authors. Thus, Egan and Akdere (2005) replicate those compiled by Williams (2003), while Aydin (2005) adapted Goodyear et al.'s (2001) study.

Other aspects to be analyzed derive from the different approach followed by various authors in their proposals. Thus we encounter very detailed taxonomies such as that of Thach and Murphy (1995), while Anderson et al. (2001), Bawane and Spector (2009), Salmon (2004, 2000), and Varvel (2007) make more general proposals as a bases to define the competencies to be taken into account in the selection, training, and professional development of teachers. This approach is also adopted by the two surveys carried out within the Spanish framework (Marcelo, 2006; Guasch, Álvarez, \& Espasa, 2010). 
Table 1

Roles Associated with Online Teaching

Studies

\begin{tabular}{|c|c|c|c|c|c|c|c|c|c|c|c|c|c|c|}
\hline Roles & 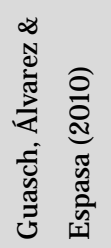 & 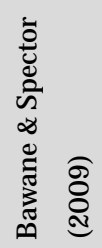 & 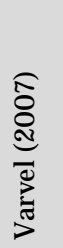 &  &  & 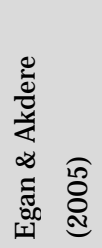 & 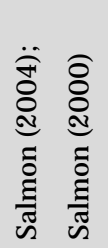 & 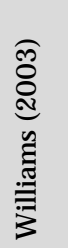 & 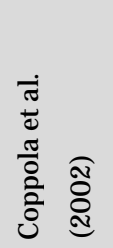 & 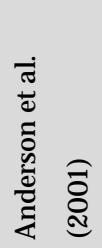 & 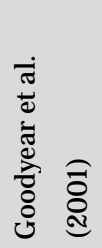 & 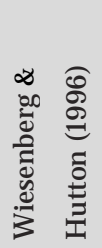 & 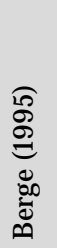 & 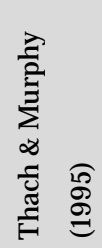 \\
\hline $\begin{array}{l}\text { Advisor, } \\
\text { Counselor, Tutor }\end{array}$ & & $\mathrm{X}$ & & $\mathrm{X}$ & $\mathrm{X}$ & & & & & & $\mathrm{X}$ & & & \\
\hline Affective & & & & & & & & & $\mathrm{X}$ & & & & & \\
\hline Cognitive & & & & & & & & & $\mathrm{X}$ & & & & & \\
\hline $\begin{array}{l}\text { Knowledgeable about } \\
\text { online processes }\end{array}$ & & & & & & & $\mathrm{X}$ & & & & & & & \\
\hline Content expert & & & & & $\mathrm{X}$ & & $\mathrm{X}$ & & & & & & & \\
\hline Content facilitator & & & & & & & & & & & $\mathrm{X}$ & & & \\
\hline $\begin{array}{l}\text { Designer-planner/ } \\
\text { Instruccional } \\
\text { designer/ } \\
\text { Organizer } \\
\end{array}$ & $\mathrm{X}$ & & $\mathrm{X}$ & $\mathrm{X}$ & $\mathrm{X}$ & $\mathrm{X}$ & & $\mathrm{X}$ & & $\mathrm{X}$ & $\mathrm{X}$ & & & $\mathrm{X}$ \\
\hline $\begin{array}{l}\text { Evaluator/ } \\
\text { assessor/ evaluation } \\
\text { specialist }\end{array}$ & & $\mathrm{X}$ & $\mathrm{X}$ & & $\mathrm{X}$ & $\mathrm{X}$ & & $\mathrm{X}$ & & & $\mathrm{X}$ & & & $\mathrm{X}$ \\
\hline $\begin{array}{l}\text { Facilitator/ site } \\
\text { facilitator- } \\
\text { proctor/process } \\
\text { facilitator } \\
\end{array}$ & & & & & $\mathrm{X}$ & $\mathrm{X}$ & & $\mathrm{X}$ & & & $\mathrm{X}$ & & & $\mathrm{X}$ \\
\hline Graphic designer & & & & & & $\mathrm{X}$ & & $\mathrm{X}$ & & & & & & $\mathrm{X}$ \\
\hline $\begin{array}{l}\text { Direct instructor/ } \\
\text { Instructor/ } \\
\text { Instructor-facilitator/ } \\
\text { Pedagogical }\end{array}$ & $\mathrm{X}$ & $\mathrm{X}$ & $\mathrm{X}$ & & & $\mathrm{X}$ & & $\mathrm{X}$ & & $\mathrm{X}$ & & $\mathrm{X}$ & $\mathrm{X}$ & $\mathrm{X}$ \\
\hline $\begin{array}{l}\text { Interpersonal } \\
\text { communicator/ } \\
\text { Communicator }\end{array}$ & & & & & & & $\mathrm{X}$ & & & & & & & \\
\hline Leader/ change agent & & & & & & $\mathrm{X}$ & & $\mathrm{X}$ & & & & & & \\
\hline
\end{tabular}


Studies

\begin{tabular}{|c|c|c|c|c|c|c|c|c|c|c|c|c|c|c|}
\hline Roles &  & 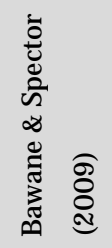 & 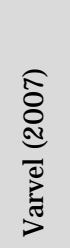 & 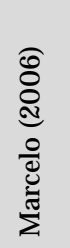 & 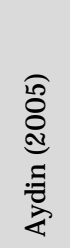 & 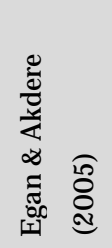 & 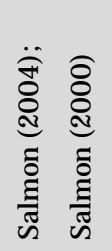 & 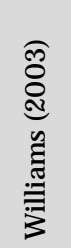 &  & 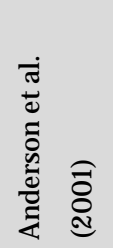 & 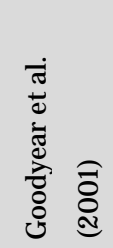 & 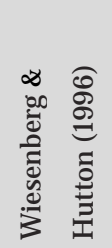 & $\begin{array}{l}\mathscr{1} \\
\text { Oे } \\
\stackrel{0}{0} \\
\stackrel{0}{0} \\
\infty\end{array}$ & 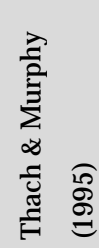 \\
\hline Librarian & & & & & & $\mathrm{x}$ & & $\mathrm{x}$ & & & & & & $\mathrm{X}$ \\
\hline $\begin{array}{l}\text { Manager/ } \\
\text { administrator/ } \\
\text { Administrative } \\
\text { manager, course } \\
\text { manager }\end{array}$ & $\mathrm{X}$ & $X$ & $X$ & $\mathrm{X}$ & $\mathrm{X}$ & $\mathrm{X}$ & & $\mathrm{X}$ & $X$ & & $\mathrm{X}$ & $X$ & $X$ & $\mathrm{X}$ \\
\hline Material producer & & & & & $\mathrm{x}$ & & & & & & & & & \\
\hline $\begin{array}{l}\text { Media publisher, } \\
\text { editor }\end{array}$ & & & & & & $\mathrm{x}$ & & $\mathrm{X}$ & & & & & & $X$ \\
\hline $\begin{array}{l}\text { Personal (personal } \\
\text { qualities and } \\
\text { characteristics) }\end{array}$ & & & $\mathrm{X}$ & & & & $\mathrm{X}$ & & & & & & & \\
\hline Professional & & $\mathrm{x}$ & & & & & & & & & & & & \\
\hline Researcher & & $\mathrm{x}$ & & & & & & & & & $\mathrm{X}$ & & & \\
\hline $\begin{array}{l}\text { Social / Discourse } \\
\text { facilitator }\end{array}$ & $\mathrm{x}$ & $\mathrm{x}$ & $\mathrm{x}$ & & & & & & & $\mathrm{x}$ & & $\mathrm{x}$ & $\mathrm{X}$ & \\
\hline $\begin{array}{l}\text { Systems expert/ } \\
\text { Consultant }\end{array}$ & & & & & & $\mathrm{x}$ & & & & & & & & \\
\hline Support staff & & & & & & $\mathrm{x}$ & & $\mathrm{x}$ & & & & & & $\mathrm{X}$ \\
\hline Technician & & & & & & $\mathrm{x}$ & & $\mathrm{x}$ & & & & & & $\mathrm{X}$ \\
\hline $\begin{array}{l}\text { Technological expert/ } \\
\text { Technologist }\end{array}$ & $\mathrm{X}$ & $\mathrm{x}$ & $\mathrm{X}$ & $\mathrm{x}$ & $\mathrm{X}$ & $\mathrm{x}$ & $\mathrm{X}$ & $\mathrm{x}$ & & & $\mathrm{X}$ & $\mathrm{x}$ & $\mathrm{X}$ & $\mathrm{X}$ \\
\hline Trainer & & & & & & $\mathrm{x}$ & & $\mathrm{x}$ & & & & & & \\
\hline
\end{tabular}


The task of synthesizing and comparing the different proposals proved to be difficult because there is no unified voice when it comes to terminology. Some terms are used with equivalent meanings, but in some cases they present certain nuances. Nonetheless, in spite of this complexity, it can be observed how the different experts and researchers contemplate categories with very similar main or basic roles in their proposals: the "technologist" role, the "administrator or manager" role, the "assessor" role or the "pedagogical" role. The latter, as can be seen in Table 1, appears to be the one identified most frequently (specifically in nine proposals). Indeed, Bawane and Spector (2009) state that the pedagogical role is the most relevant.

Below, based on the structure of roles identified, we propose in Table 2 a classification in which the competencies associated with each of the diverse roles are described. The identification of these competencies and their link with the teaching roles has been built on the basis of the analysis of surveys collected in Table 1 as well as on the discussions that took place in a focus group organized at the A Coruña University. This focused group was formed with nine teachers, who were representative of the faculty characteristics and experienced in online teaching. There were five men and four women, six of them belonged to a scientific- health and technical background whereas three of them to a human sciences and social-legal background. There were six full time faculty and three hired teachers ${ }^{1}$. A whole day work session was carried out with the focus of analyzing and discussing the different authors' proposals collected in Table 1. The goal of this discussion was to delimit the aspects considered to be relevant in the profile of the classroom faculty, who would perform as virtual teachers. The reference competences for this study, collected in Table 2, are those associated to the pedagogical role. They are compiled in the applied questionnaire items (Table 5).

${ }^{1}$ Faculty in the Public Spanish University System belong to two administrative categories. Full time faculty become civil servants after a public examination. Hired teachers are hired for certain periods of time either to temporarily substitute for full time faculty or to participate in research projects. It is not possible to exactly assimilate these categories to those of other international universities. That's why the translation avoided such terms as assistant professors, associate professors, tenured, or tenure-track. 
Table 2

Competencies Associated with the Roles of the Teachers Performing Online

\begin{tabular}{|c|c|c|}
\hline Main roles & Secondary roles & Competencies \\
\hline \multirow{5}{*}{$\begin{array}{c}\text { (1) } \\
\text { Pedagogical }\end{array}$} & $\begin{array}{l}\text { Instructional } \\
\text { designer and } \\
\text { developer }\end{array}$ & $\begin{array}{l}\text { - Design the teaching proposal at a general level and in each } \\
\text { of its phases or elements } \\
\text { - Draft and develop digital materials } \\
\text { - Draft and develop learning activities } \\
\text { - Draft and develop assessment activities }\end{array}$ \\
\hline & Content expert & $\begin{array}{l}\text { - Draft and develop course contents } \\
\text { - Link the subject with scientific, social and cultural } \\
\text { phenomena }\end{array}$ \\
\hline & Tutor & - Organize and promote different tutorial modalities \\
\hline & $\begin{array}{l}\text { Organizer and } \\
\text { facilitator }\end{array}$ & - Organize and facilitate student participation \\
\hline & Professional & $\begin{array}{l}\text { - Organize and promote self training and teacher } \\
\text { professional development }\end{array}$ \\
\hline $\begin{array}{c}(2) \\
\text { Social }\end{array}$ & & $\begin{array}{l}\text { - Maintain a cordial learning environment } \\
\text { - Resolve conflict in an amicable manner } \\
\text { - Refrain from undesirable behaviours } \\
\text { - Act as information facilitator } \\
\text { - Improve the learning environments } \\
\text { - Send messages to support students } \\
\text { - Give feedback to student interactions and } \\
\text { communications } \\
\text { - Dynamize and promote interaction with the students } \\
\text { - Keep the classroom/ course/ university degree coordinator } \\
\text { informed about the progress and the possible problems } \\
\text { that may arise }\end{array}$ \\
\hline $\begin{array}{l}\text { (3) } \\
\text { Evaluator }\end{array}$ & & $\begin{array}{l}\text { - Assess students' work according to established criteria } \\
\text { - Monitor individual and group progress } \\
\text { - Assess individual and group performance } \\
\text { - Evaluate the course/ program }\end{array}$ \\
\hline
\end{tabular}




\begin{tabular}{|c|c|c|}
\hline Main roles & Secondary roles & Competencies \\
\hline $\begin{array}{c}(4) \\
\text { Administrator/ } \\
\text { manager }\end{array}$ & & $\begin{array}{l}\text { - Manage time and course } \\
\text { - Demonstrate leadership qualities } \\
\text { - Establish rules and regulations } \\
\text { - Follow efficiently management and administrative } \\
\text { procedures (e.g.: request to create online classrooms, } \\
\text { request to integrate technological support for performing } \\
\text { learning activities, enrolment management, student } \\
\text { enrolment in the online environment, etc.) } \\
\text { - Maintain contact with the rest of the teaching and } \\
\text { administrative team }\end{array}$ \\
\hline $\begin{array}{c}\text { (5) } \\
\text { Technologist }\end{array}$ & & $\begin{array}{l}\text { - Select the appropriate resource for learning } \\
\text { - Awareness of the technical procedures to develop } \\
\text { multimedia content and to adapt them to e-learning } \\
\text { environments } \\
\text { - Suggest resources to the students (resource provider) } \\
\text { - Stay up to date with and learn about new software needed } \\
\text { for the teaching process } \\
\text { - Awareness of the features and uses of the main platforms, } \\
\text { resources and virtual tools } \\
\text { - Awareness of the procedures required to manage as a } \\
\text { teacher both synchronous and asynchronous } \\
\text { communication tools }\end{array}$ \\
\hline $\begin{array}{c}\text { (6) } \\
\text { Advisor/ } \\
\text { Counsellor }\end{array}$ & & $\begin{array}{l}\text { - Suggest measures to enhance performance } \\
\text { - Provide guidance based on student needs } \\
\text { - Offer advice, suggestions and clarify doubts } \\
\text { - Motivate the students }\end{array}$ \\
\hline $\begin{array}{c}\text { (7) } \\
\text { Personal }\end{array}$ & & $\begin{array}{l}\text { - Comply with ethic and legal standards } \\
\text { - Adopt a positive attitude and commitment to e-learning } \\
\text { - Show sensitivity during the communication process and } \\
\text { in online contacts }\end{array}$ \\
\hline $\begin{array}{c}\text { (8) } \\
\text { Researcher }\end{array}$ & & $\begin{array}{l}\text { - Conduct research into classroom teaching } \\
\text { - Interpret and integrate research findings in teaching } \\
\text { - Develop reflexive processes about, in and for the teaching } \\
\text { practice }\end{array}$ \\
\hline
\end{tabular}

Note. Adapted from Bawane and Spector (2009) 


\section{Purpose of the Study}

Taking into account that many higher education institutions, originally offering traditional classroom teaching, are introducing e-learning practices, it is important to identify how the teaching staff, used to face-to-face interactions, are affected by their incorporation into online teaching, specifically the changes they face with regard to the new required competencies. A cross-sectional survey of a descriptive and explorative nature has been conducted in order to answer these concerns. Its core objective has been focused on obtaining information about the level of proficiency that faculty say they have with respect to the pedagogical competencies of an online teacher and about their interest in training programs (understood as their willingness to amplify and improve their training in these competencies). In particular, the study has been carried out with faculty who are incorporating ICT as well as developing online teaching initiatives as a complement to their face to face teaching.

The research proposed the following hypotheses:

- Hypothesis 1: The level of proficiency shown by university teachers regarding pedagogical competencies for e-learning systems is associated with occupational variables (in particular, academic category, scientific sphere, and university teaching experience in virtual environments).

- Hypothesis 2: The interest of university teachers in training programs for the acquisition of pedagogical competencies associated with e-learning systems is associated with occupational variables (in particular, academic degree, scientific environment, and university teaching experience in virtual environments).

- The connections between the proficiency level and the training interest regarding the pedagogical competencies relative to e-learning have also been analyzed.

\section{Study Context}

The survey was carried out at the A Coruña University (hereinafter UDC). UDC is a public university, located in the north-west of the Iberian Peninsula (www.udc.es), and it has 25 education centres. It offers 42 official bachelor degree programs, 53 master degree programs, and $46 \mathrm{PhD}$ programs. Table 3 collects the numerical data of faculty and students at UDC, according to gender. 
Table 3

UDC Teachers and Students

\begin{tabular}{|l|c|c|c|}
\cline { 2 - 4 } \multicolumn{1}{c|}{} & Women & Men & TOTAL \\
\hline Teachers & 512 & 946 & 1458 \\
\hline Bachelor students & 9829 & 9752 & 19581 \\
\hline Master degree students & 618 & 436 & 1054 \\
\hline PHD Students & 682 & 680 & 1362 \\
\hline
\end{tabular}

Between 2000 and 2005 UDC developed the "Plan de Innovación Tecnolóxica" or "Technologic Innovation Plan" (INNOVATE) to integrate ICT into myriad fields: information, management, education, and research. On the other hand, in order to improve university teaching through the use of ICT, the project ITEM (Innovación Tecnológica y Enseñanza Multimedia - Technological Innovation and Multimedia Teaching) was drafted. Bates and Sangrà (2011) chose UDC as one of their case studies. Subsequently, new measures were taken into consideration in order to increase the virtual educational offering and to enhance the training of the teaching staff in order to take over the development of online subjects. The impulse and the increased use of online teaching have brought about an institutional debate on the requirements that such an initiative might imply, specifically in terms of teaching. It is against this background and under these premises that the study we present here arose.

\section{Methodology}

A nonexperimental quantitative survey was designed (Cohen \& Manion, 1990; McMillan $\&$ Schumacher, 2005). An online questionnaire was drafted and sent via electronic media.

This article presents the results reached in Section II within the questionnaire relating to the pedagogical competencies of the university teaching staff associated with the use of e-learning. The analysis focuses on their current level of proficiency, as well as on their interest in increasing their training. Each item is assessed on a 5-point Likert scale. This scale collects teacher's perceptions, understanding 5 is the higher rate and 1 the lowest.

In order to guarantee the validity conditions, the first version of the questionnaire went through a subject-matter expert content validation and was subjected to a pilot study. As for its reliability, Cronbach's alpha internal reliability index was used. The internal consistency coefficients obtained in the "pedagogical competencies" section have turned 
out to be considerably high: the category "level of proficiency": $\alpha=0,944$; the category "training needs": $\alpha=0,953$.

\section{Participants}

The sampling technique was non-probabilistic, an accidental or convenience sample (Cohen \& Manion, 1990; McMillan \& Schumacher, 2005). The sample population was defined by the teaching staff practicing within the online teaching system from the A Coruña University.

The sample collected (166 questionnaires) exceeded the sample required according to the formula for finite populations as proposed by Arnal, del Rincón, and Latorre (1992). The distribution of the participants in the survey is shown in Table 4.

Table 4

Characteristics of the Sample Population Arranged by the Categories: Administrative, Scientific Environment And Teaching Experience within Virtual Environments

\begin{tabular}{|l|c|c|c|}
\hline \multicolumn{2}{|l|}{ Identification variable } & $n$ & $\%$ \\
\hline Administrative category Full time faculty & 107 & 64,5 \\
\cline { 2 - 4 } & Hired teachers & 59 & 35,5 \\
\hline Scientific environment & Scientific - health and technical & 104 & 62.7 \\
\cline { 2 - 4 } & Human sciences and social- legal & 62 & 37.3 \\
\hline \multirow{2}{*}{$\begin{array}{l}\text { Teaching experience in } \\
\text { virtual environments }\end{array}$} & Less than 1 year & 26 & 16.3 \\
\cline { 2 - 4 } & Between 1 and 2 years & 37 & 23.1 \\
\cline { 2 - 4 } & Between 3 and 4 years & 55 & 34.4 \\
\cline { 2 - 4 } & Between 5 and 6 years & 17 & 10.6 \\
\cline { 2 - 4 } & More than 6 years & 25 & 15.6 \\
\hline
\end{tabular}

\section{Data Results}

Below we present an analysis of the responses for the items from the section entitled "pedagogical competencies of the university teaching staff regarding the use of elearning", both at a global level and taking into account various sampling segments. 
At a descriptive level we find that, according to the "level of proficiency" in pedagogical competencies applied to the e-learning environment, as shown in Table 5, the mean scores obtained show that the teaching staff from the UDC possesses what could be categorized as an average level of proficiency.

Table 5

Mean Difference on the Level of Proficiency and Training Needs Regarding Pedagogical Competencies Applied to E-Learning

\begin{tabular}{|c|c|c|c|c|c|c|c|c|c|c|c|c|}
\hline & \multicolumn{4}{|c|}{$\begin{array}{l}\text { Level of Training } \\
\text { proficiencyneeds }\end{array}$} & \multicolumn{8}{|c|}{ Mean differences } \\
\hline & \multirow[b]{2}{*}{  } & \multirow[b]{2}{*}{ 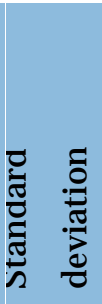 } & \multirow[b]{2}{*}{$\sum_{\Sigma}^{\infty}$} & \multirow[b]{2}{*}{  } & \multirow{2}{*}{ 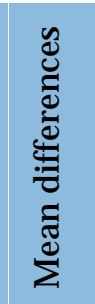 } & \multirow[b]{2}{*}{ 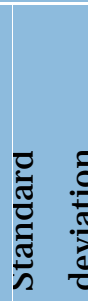 } & \multirow{2}{*}{ 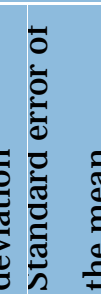 } & \multicolumn{2}{|c|}{$\begin{array}{l}\text { 95\% Confidence } \\
\text { interval }\end{array}$} & \multirow[b]{2}{*}{$\mathrm{t}$} & \multirow[b]{2}{*}{ df } & \multirow[b]{2}{*}{ 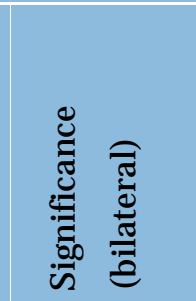 } \\
\hline & & & & & & & & Superic & or Inferior & & & \\
\hline $\begin{array}{l}\text { Design the teaching } \\
\text { proposal at a } \\
\text { general level and in } \\
\text { each of its phases or } \\
\text { elements }\end{array}$ & 2.53 & 1.209 & 3.18 & 1.619 & -.651 & 1.719 & .133 & -.914 & -.387 & -4.876 & 165 & $\begin{array}{c}.000 \\
\text { Relative } \\
\text { significance }\end{array}$ \\
\hline $\begin{array}{l}\text { Draft and develop } \\
\text { course contents }\end{array}$ & 2.78 & 1.130 & 3.28 & 1.590 & -.500 & 1.698 & .132 & -.760 & -.240 & -3.795 & 165 & $\begin{array}{c}.000 \\
\text { Relative } \\
\text { significance }\end{array}$ \\
\hline $\begin{array}{l}\text { Draft and develop } \\
\text { learning activities }\end{array}$ & 2.53 & 1.174 & 3.39 & 1.590 & -.855 & 1.721 & .134 & -1.119 & -.592 & -6.405 & 165 & $\begin{array}{c}.000 \\
\text { Relative } \\
\text { significance }\end{array}$ \\
\hline $\begin{array}{l}\text { Draft and develop } \\
\text { assessment } \\
\text { activities }\end{array}$ & 2.37 & 1.198 & 3.34 & 1.632 & -.970 & 1.784 & .138 & -1.243 & -.697 & -7.006 & 165 & $\begin{array}{c}.000 \\
\text { Relative } \\
\text { significance }\end{array}$ \\
\hline $\begin{array}{l}\text { Draft and develop } \\
\text { digital materials }\end{array}$ & 2.43 & 1.257 & 3.39 & 1.606 & -.952 & 1.808 & 3.140 & -1.229 & -.675 & -6.781 & 165 & $\begin{array}{c}.000 \\
\text { Relative } \\
\text { significance }\end{array}$ \\
\hline $\begin{array}{l}\text { Organize and } \\
\text { promote teacher } \\
\text { training and } \\
\text { professional } \\
\text { development } \\
\text { programs }\end{array}$ & 2.46 & 1.163 & 3.43 & 1.593 & -.970 & 1.653 & .128 & -1.223 & -.717 & -7.560 & 165 & $\begin{array}{c}.000 \\
\text { Relative } \\
\text { significance }\end{array}$ \\
\hline
\end{tabular}




\begin{tabular}{|c|c|c|c|c|c|c|c|c|c|c|c|}
\hline $\begin{array}{l}\text { Organize and } \\
\text { facilitate student } \\
\text { participation }\end{array}$ & 2.521 .169 & 3.57 & 1.566 & 1.048 & 1.658 & .129 & -1.302 & -.794 & -8.145 & 165 & $\begin{array}{c}.000 \\
\text { Relative } \\
\text { significance }\end{array}$ \\
\hline $\begin{array}{l}\text { Link the content of } \\
\text { the course with } \\
\text { scientific, social and } \\
\text { cultural phenomena }\end{array}$ & 2.521 .148 & 3.53 & 1.567 & 1.006 & 1.650 & .128 & -1.259 & -.753 & -7.857 & 165 & $\begin{array}{c}.000 \\
\text { Relative } \\
\text { significance }\end{array}$ \\
\hline $\begin{array}{l}\text { Organize and } \\
\text { promote different } \\
\text { tutorial methods }\end{array}$ & 2.541 .204 & $=3.46$ & 1.556 & -.922 & 1.618 & .126 & -1.170 & -.674 & -7.339 & 165 & $\begin{array}{c}.000 \\
\text { Relative } \\
\text { significance }\end{array}$ \\
\hline
\end{tabular}

The competencies in which the teaching staff indicated they had higher levels of proficiency were the following: "draft and develop course contents (item 2)" with a mean of 2.78; "organize and promote different tutorial methods (item 9)" with a mean of 2.54; "draft and develop learning activities (item 3)" with a mean of 2.53; and "link the content of the course with scientific, social and cultural phenomena (item 8)" with a mean of 2.52, similar to item 7 ("organize and facilitate student participation").

On the other hand, item 4 ("draft and develop assessment activities") obtained the lowest mean score with 2.37 .

Regarding "training needs" (Table 5), certain aspects appear to reach a medium-high level, such as the following: "organize and facilitate student participation" (3.57 mean); "link the content of the course with scientific, social and cultural phenomena" (3.53 mean); and "organize and promote different tutorial methods" (3.46 mean). The items with the lowest scores are those related to "design the teaching proposal at a general level and in each of its phases or elements" (3.18 mean) and "draft and develop course contents" (3.28 mean).

On the whole, the means are considered to be quite high, meaning that the faculty from UDC show a considerable interest in teaching training programs in order to enhance their pedagogical competencies within the e-learning environment.

In the following lines there is a comparison, through mean ranking, between the level of proficiency and the training needs for the acquisition of pedagogical competencies within the e-learning environment (Figure 1). As shown below, the training needs obtain higher mean ranks than the training level manifested by the teaching staff in each and every one of the different items. 


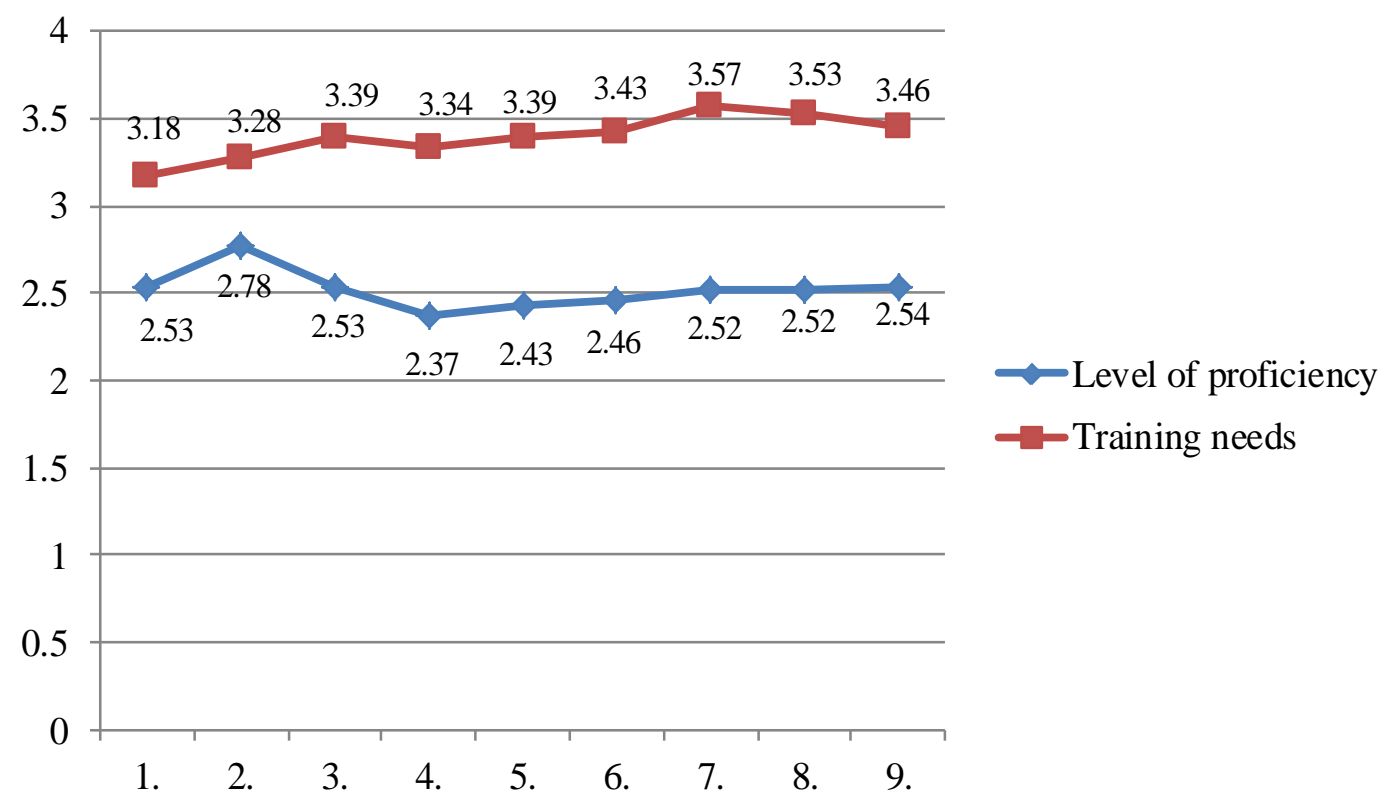

$\mathbf{1}=$ Design the teaching proposal at a general level and in each of its phases or elements

$\mathbf{2}=$ Draft and develop course contents

3= Draft and develop learning activities

$\mathbf{4}=$ Draft and develop assessment activities

$\mathbf{5}=$ Draft and develop digital materials

$\mathbf{6}=$ Organize and promote teacher training and professional development programs

$7=$ Organize and facilitate student participation

$\mathbf{8}=$ Link the content of the course with scientific, social and cultural phenomena

$\mathbf{9}=$ Organize and promote different tutorial methods

Figure 1. Comparison between the proficiency level and the training needs for the acquisition of pedagogical competencies within the e-learning environment.

It is worth mentioning that the items with a minor difference between the proficiency level and the training needs are "draft and develop course contents" (a difference of 0.5 points) and "design the teaching proposal at a general level and in each of its phases or elements" (a difference of 0.65 points).

As for the items with a higher difference, they are "organize and facilitate student participation" (a difference of 1.05 points), and "link the content of the course with scientific, social and cultural phenomena" (a difference of 1.01 points).

The results of the Student t test (Table 5) show how, for a confidence interval of 95\%, there are significant mean differences between the items belonging to both categories 
(level of proficiency and training needs for the acquisition of pedagogical competencies within e-learning environments).

Next, we carried out an inferential analysis of the university teachers' pedagogical competencies in e-learning, according to the "administrative category" variable.

Table 6

Mann-Whitney Test ("Administrative Category” Variable)

\begin{tabular}{|c|c|c|c|c|c|c|}
\hline $\begin{array}{l}\text { Compared } \\
\text { variables }\end{array}$ & $\begin{array}{l}\text { Administrative } \\
\text { category }\end{array}$ & n & $\begin{array}{l}\text { Average } \\
\text { range }\end{array}$ & $\begin{array}{l}\text { Rank } \\
\text { summary }\end{array}$ & \multicolumn{2}{|l|}{ Contrast statistics } \\
\hline $\begin{array}{l}\text { Level of } \\
\text { proficiency in }\end{array}$ & $\begin{array}{l}\text { Full time } \\
\text { faculty }\end{array}$ & 105 & 77.09 & 8094.50 & \multicolumn{2}{|c|}{$\begin{array}{l}\text { Mann-Whitney U } \\
\text { Wilcoxon W } 2529.500\end{array}$} \\
\hline pedagogical & Hired & 59 & 92.13 & 5435.50 & Z & 8094.500 \\
\hline competencies & Total & 164 & & & $\begin{array}{l}\text { Asymptotic } \\
\text { significance } \\
\text { (bilateral) }\end{array}$ & $\begin{array}{l}-1.949 \\
.051\end{array}$ \\
\hline $\begin{array}{l}\text { Training needs } \\
\text { for the }\end{array}$ & $\begin{array}{l}\text { Full time } \\
\text { faculty }\end{array}$ & 105 & 79.45 & 8342.00 & \multirow{2}{*}{$\begin{array}{l}\text { Mann-Whitney U } \\
\text { Wilcoxon W } \\
\text { Z }\end{array}$} & 2777.000 \\
\hline acquisition of & Hired & 59 & 87.93 & 5188.00 & & 8342.000 \\
\hline $\begin{array}{l}\text { pedagogical } \\
\text { competencies }\end{array}$ & Total & 164 & & & $\begin{array}{l}\text { Asymptotic } \\
\text { significance } \\
\text { (bilateral) }\end{array}$ & $\begin{array}{l}-1.106 \\
.269\end{array}$ \\
\hline
\end{tabular}

According to the results obtained in Table 6, we can affirm that for the variable "level of proficiency in pedagogical competencies", the p-value of 0.051 is within the non significance limit. Based on the mean ranges analysis, it can be concluded that the hired teachers possess a higher level of proficiency in pedagogical competencies compared to the full time faculty. As for the training needs for the acquisition of pedagogical competencies, and taking into account the $0.269 \mathrm{p}$-value, we can assert that there are no significant differences according to the administrative category of the teachers.

As regards the inferential analysis according to the "scientific environment" variable and taking into account the results in Table 7, the conclusion is that there are no significant differences either. 
Table 7

Mann-Whitney Test (“Scientific Environment” Variable)

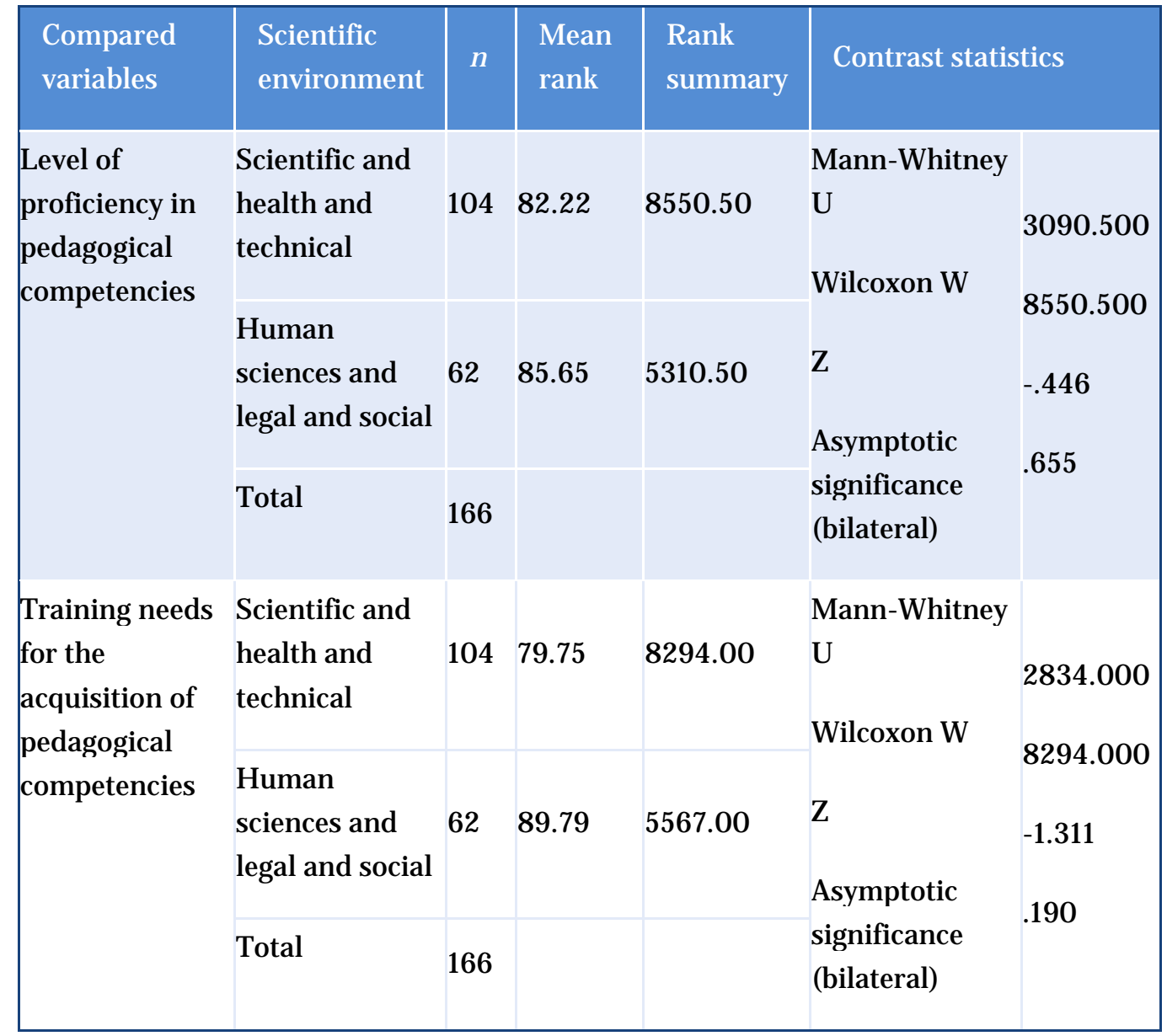

Based on the results obtained in Table 8, it can be asserted that there are significant differences in the level of proficiency in pedagogical competencies in e-learning according to the level of teaching experience in virtual environments ( $p$-value $=0.001$ ). Thus, the higher the level of teaching experience in distance education, the higher the level of proficiency in pedagogical competencies. Simple observation of the mean ranges bears out this fact.

On the other hand, the p-value of 0.702 leads to acceptance of the null hypothesis of variable independence for the variables "training needs for the acquisition of pedagogical competencies" and "university teaching experience within virtual environments". 
Table 8

Kruskal-Wallis Test (Variable: "Teaching Experience in Virtual Environments")

\begin{tabular}{|c|c|c|c|c|c|}
\hline $\begin{array}{l}\text { Compared } \\
\text { variables }\end{array}$ & $\begin{array}{l}\text { Teaching } \\
\text { experience in } \\
\text { virtual } \\
\text { environments } \\
\end{array}$ & $\mathrm{n}$ & $\begin{array}{l}\text { Mean } \\
\text { rank }\end{array}$ & \multicolumn{2}{|c|}{ Contrast statistics } \\
\hline \multirow{6}{*}{$\begin{array}{l}\text { Level of proficiency } \\
\text { in pedagogical } \\
\text { competencies }\end{array}$} & Less than 1 year & 26 & 55.69 & \multirow{6}{*}{$\begin{array}{l}\text { Chi -square } \\
\mathrm{df} \\
\text { Asymptotic } \\
\text { significance }\end{array}$} & \multirow{6}{*}{$\begin{array}{l}18.298 \\
4 \\
.001\end{array}$} \\
\hline & 1 - 2 years & 37 & 67.47 & & \\
\hline & 3 - 4 years & 55 & 87.45 & & \\
\hline & 5 - 6 years & 17 & 92.21 & & \\
\hline & $\begin{array}{l}\text { More than } 6 \\
\text { years }\end{array}$ & 25 & 102.32 & & \\
\hline & Total & 160 & & & \\
\hline \multirow{6}{*}{$\begin{array}{l}\text { Training needs for } \\
\text { the acquisition of } \\
\text { pedagogical } \\
\text { competencies }\end{array}$} & Less than 1 year & 26 & 71.10 & \multirow{6}{*}{$\begin{array}{l}\text { Chi -square } \\
\mathrm{df} \\
\text { Asymptotic } \\
\text { significance }\end{array}$} & \multirow{6}{*}{$\begin{array}{l}2.184 \\
4 \\
.702\end{array}$} \\
\hline & 1 - 2 years & 37 & 88.07 & & \\
\hline & 3 - 4 years & 55 & 79.80 & & \\
\hline & 5 - 6 years & 17 & 78.09 & & \\
\hline & $\begin{array}{l}\text { More than } 6 \\
\text { years }\end{array}$ & 25 & 82.26 & & \\
\hline & Total & 160 & & & \\
\hline
\end{tabular}

\section{Discussion and Implications}

When the study was carried out, faculty possessed different levels of proficiency and experience in the use of e-learning. Some of them had already participated in the Innovate Plan for the integration of ICT and developed blended-learning modality subjects. An aspect to be considered is that the research also incorporated faculty who were beginners in the intensive use of the ICT and, specifically, in the virtualization project of their subjects. This explains the dispersion on the frequencies obtained on the Likert scale and, as a consequence, the means reached during the inquiries of the level of proficiency. Anyway, and in spite of the fact that the means are very close, it is worth discussing the two aspects that obtained the highest and the lowest means. Content drafting is the aspect in which the subjects declared the highest level of proficiency. This shows that it is surely the one that is used the most, and probably one of the first actions performed by a teacher when first engaging in e-learning. On the contrary, the item with the lowest score refers to assessment. And, indeed, assessment represents one of the most controversial actions and it remains problematic within virtual environments (J ohn \& Wheeler, 2008). 
The results obtained regarding training needs are considerably higher and they reflect not only the willingness of the teaching staff to improve their training, but also their awareness of the changes and requirements entailed by e-learning. Facilitating student participation is what faculty identify as their greater training need. The commitment of students to their own training is a fundamental element in an active and constructivist learning model and thus student participation turns out to be essential (Bach, Haynes, \&Smith, 2007).

The analysis of the mean differences through the student $t$ test (Table 5) reveals the fact that in every case the training needs exceed the level of proficiency recognized by the faculty.

Regarding the hypotheses presented in the survey, the inferential analysis allows us to conclude that the level of proficiency is higher for the hired teachers (they are younger teachers and with less teaching experience who teach face to face and deal with higher pressure regarding training to consolidate their careers in the Spanish University System). The teachers with more teaching experience in virtual environments, regardless of their administrative category, report a higher level of domain in the pedagogical competences. On the contrary, neither the administrative category, the scientific environment, nor teaching experience in virtual environments implies significant differences regarding training needs.

The information obtained through this survey is highly relevant at both a local and a global level. In the particular context of UDC, the results have been decisive in informing policies on the integration of ICT and e-learning (especially regarding teaching training). On the other hand, we also hope that our survey contributes to enriching the knowledge available on the roles of teachers performing online and on the training they may need to carry out their tasks. We could also add that, in a certain way, we accomplished one of our initial objectives regarding the use of the literature available to support the actions that we needed to undertake and, by making the voice of the faculty heard through the investigation we conducted, to build a body of knowledge that has been doubly validated (by experts and their publications and by teachers involved in online teaching).

The survey was not meant to merely develop theoretical knowledge, but rather one of its key features was to place a marked emphasis on practice. The survey context required responses which were supposed to facilitate the decision making process. This double inquiry turned out to be both valuable and productive.

With this survey, we also tried to question and avoid the lineal transfer of the tasks of traditional classroom teaching to online teaching, especially in its more deficient aspects, as Baran, Correia, and Thompson (2011) warn us. Hence the emphasis on identifying and systematizing the roles and competencies of the faculty performing in virtual environments and on promoting awareness and evaluation of the same among the teachers involved. The questionnaire was not a mere research tool, as it also 
constituted a reference document for individual and collective critical reflections on virtual teaching. Indeed, it served not only to collect data, but also to help faculty to reflect on the competencies characterizing their task in online teaching and to revise their performance as well as their possibilities for professional training in their particular context.

The analysis of the different proposals available and their classification in Tables 1 and 2 turned out to be complex - and even puzzling - at the beginning of the survey. Identifying the disparity of purposes, starting points, and methodological designs supporting such proposals helped us understand the differences. On the other hand, by means of the focus group discussion, we could draft our own list of pedagogical teaching competencies, as a basis on which to define the online teacher profile at A Coruña University, since the debate on the roles and competencies of the online teacher must be placed within the framework of reflections on the teacher model (whether implicit or explicit). And any reference to the teacher model inexorably leads to consideration of the teaching training model.

We are aware of the current controversy regarding teaching competencies and competence based training, and, above all, we understand and support the warnings of those who perceive these approaches as a return to the past and as a revival of technological models based on efficiency and accountability. Nonetheless, according to the current view of the competencies movement and based on the definitions elaborated by several authors (Zabalza, 2003; Le Boterf, 2000) and organizations (UNESCO, 2008), we consider that its use could be beneficial as another reference point in the configuration of teaching performance and training (McDiarmid \& Clevenger-Bright, 2008). We reject technological models of teacher training like those developed in the '70s through CBTE programs. The premise of considering faculty as adult students is indisputable, and, as a consequence, it is essential to recognize their autonomy as well as their learning and transformation capacity (Darling-Hammond \& Sykes, 1999; Feiman-Nemser, 2008). As Borko and Putnam (1996) pointed out, new learning is built on previous knowledge and experience. Hence the importance of identifying and making the teaching staff aware of their basic knowledge. This will be of use to filter, interpret, and/or question future acquisitions. For this reason, training cannot be conceived as a static process directed by experts who establish rigid learning sequences. Its purpose is not, and must not be, solely to develop technical routines and skills, but to promote teacher empowerment, facilitating thus professional development (Minott, 2011).

The training initiatives carried out at the UDC were developed under diverse formats, both of a vertical and a horizontal nature. There has been an organization of courses and workshops with an expository and directive approach, but the development of collaborative training strategies was also encouraged: through the creation of working groups among the teachers to analyze the changes derived from the incorporation of technology and to draw up innovation projects by using ICT. In any case, the approach of the survey as well as that of the promoted training proposals implied the integration 
of technology and pedagogy. Online teachers are first and foremost teachers (Bawane \& Spector, 2009). According to the conceptualization proposed by Shulman (1987) regarding the three types of professional knowledge - subject matter knowledge, pedagogical knowledge, and pedagogical content knowledge - we consider that technology must be integrated accordingly in these three types of professional knowledge. This would improve the teaching process and facilitate teaching innovation. In short, technology should support pedagogy, no matter the approach chosen by the teacher: (a) technology functioning as replacement, (b) amplification, or (c) transformation (Hughes, 2005). Furthermore, technology should also serve to boost the learning process and the professional development of the teaching staff (Sangrà \& González Sanmamed, 2004b). 


\section{References}

Anderson, T., Rourke, L., Garrison, D., \&Archer, W. (2001). Assessing teaching presence in a computer conferencing context. J ournal of Asynchronous Learning Networks, 5(2),1-17. Retrieved from http://sloanconsortium.org/publications/jaln_main

Ardizzone, P., \& Rivoltella, P. C. (2004). E-learning. Métodos e instrumentos para la innovación de la enseñanza universitaria. Málaga: Ediciones Aljibe.

Arnal, J ., Del Rincón, D., \& Latorre, A. (1992). Investigación educativa. Fundamentos y metodología. Barcelona: Labor.

Aydin, C. (2005). Turkish mentors' perception of roles, competencies and resources for online teaching. Turkish Online J ournal of Distance Education, 6(3). Retrieved from http:// tojde.anadolu.edu.tr/

Bach, S., Haynes, Ph., \& Smith, J . L. (2007). Online learning and teaching in higher education. London: Open University Press.

Baran, E., Correia, A. P., \& Thompson, A. (2011). Transforming online teaching practice: Critical analysis of the literature on the roles and competencies of online teachers. Distance Education, 32(3), 421-439.

Barro, S., \& Burillo, P. (Dir.) (2006). Las TIC en el sistema universitario español: Un análisis estratégico. Resumen ejecutivo. Madrid: Conferencia de Rectores de las Universidades Españolas.

Bates, A. W. \& Poole, G. (2003). Effective teaching with technology in higher education. San Franciso: J ossey-Bass.

Bates, A. W., \& Sangrà, A. (2011). Managing technology in higher education. San Franciso: J ossey-Bass.

Bautista, G., Borges, F., \& Forés, A. (2006). Didáctica universitaria en entornos virtuales de enseñanza-aprendizaje. Madrid: Nancea.

Bawane, J ., \& Spector, J . (2009). Prioritization of online instructor roles: Implications for competency-based teacher education programs. Distance Education, 30(3), 383- 397. doi:10.1080/01587910903236536

Belisle, C., \& Linard, M. (1996). Quelles nouvelles compétences des acteurs de la formation dans le contexte des TIC? Educación Permanente, 127, 19-47.

Berge, Z. L. (1995). Facilitating computer conferencing: Recommendations from the field. Educational Technology, 35(1), 22- 30. 
Berge, Z. (2008). Changing instructor's roles in virtual worlds. Quarterly Review of Distance Education, 9(4), 407-414.

Borko, H., \& Putnam, R. T. (1996). Learning to teach. In D. C. Berliner \& R. C. Calfee (Eds.), Handbook of educational psychology (pp. 673-708). New York: Macmillan.

Bullen, M., \&Janes, D. (2007) (Eds.). Making the transition to e-learning: Strategies and isues. Hershey, PA, Ideas Group.

Burbules, N., \& Callister, T. (2000). Universities in transition: The promise and the challenge of new technologies. Teachers College Record, 10(2), 271-293.

Carr-Chellman, A. A. (Ed.) (2005). Global perspectives on elearning: Rhetoric and reality. Thousand Oaks : Sage Publications.

Cohen, L., \& Manion, L. (1990). Métodos de investigación educativa. Madrid: La Muralla.

Collison, G, Elbaum, B., \& Haavind, S. (2000). Facilitating onlinelearning : Effective strategies for moderators. Madison, WI, USA: Atwood Publishing.

Coppola, N., Hiltz, S., \& Rotter, N. (2002). Becoming a virtual professor: Pedagogical roles and asynchronous learning networks. J ournal of Management Information Systems, 18(4), 169- 189. Retrieved from http:// www.jmisweb.org/toppage/ index.html

Darling-Hammond, L., \& Sykes (Eds.). Teaching as the learning profession. Handbook of policy and practice. San Francisco: J ossey-Bass

Egan, T. M., \&Akdere, M. (2005). Clarifying distance education roles and competencies: Exploring similarities and differences between professional and student-practitioner perspectives. American J ournal of Distance Education, 19(2), 87- 103. doi: 10.1207/s15389286ajde1902_3.

Epper, R., \& Bates, A. (2001). Teaching faculty how to use technology: Best practices from leading institutions. Westport: The American Council on Education and The Oryx Press.

Espasa, A., Guash, T., \& Alvarez, I. (2009, August). A methodological approach to identify teacher's ICT competencias in online learning environments in higher education. 13 $3^{\text {th }}$ Biennial Conference EARLI, Amsterdam.

European Institute for E-Learning (EIfEL). The eLearning Competency Framework for Teachers and Trainers. Produced by eTTNet TWG 2 Based on EIfEL standards. Retrieved from http:/ / www.eife-l.org/ publications/ competencies/ttframework 
Feiman-Nemser, S. (2008). Teacher learning: How do teachers learning to teach? In M. Cochran-Smith, S. Feiman-Nemser \&J . McIntyre (Eds.), Handbook of research on teacher education : Enduring questions in changing contexts (3rd ed.) (pp. 697-705). Nueva York: Routledge.

Goodyear, P., Salmon, G., Spector, J . M., Steeples, C., \& Tickner, S. (2001). Competences for online teaching: A special report. Educational Technology Research and Development, 49(1), 65- 72. Retrieved from http:// www.springerlink.com/ content/ q101330606t10301/fulltext.pdf

Guasch, T., Alvarez, I., \&Espasa, A. (2010). University teacher competencies in a virtual teaching / learning environment: Analysis of a teacher training experience. Teaching and Teacher Education, 26(2), 199- 206. doi:10.1016/j.tate.2009.02.018

Hanna, D. (2002) (Ed.). La enseñanza universitaria en la era digital. Bacelona: Octaedro.

Hughes, J . (2005). The role of teacher knowledge and learning experiences in forming technology - integrated pedagogy. J ournal of Technology and Teacher Education, 13(2), 277-302.

International Board of Standards for Training, Performance and Instruction - IBSTPI (2003). Competencias del instructor. Retrieved from http:// www.ibstpi.org/downloads/instructor_competencies_in_spanish.pdf

International Society for Technology in Education (ISTE). (2008). Nets for teachers. Retrieved from http:// www.iste.org/ standards/ nets-for-teachers/nets-forteachers-2008.aspx

J ohn, P. D., \&Wheeler, S. (2008). The digital classroom. Harnessing technology for the future of learning and teaching. New York: Routledge.

Kearsely, G. (2000). Online education: Learning and teaching in cyberspace. Belmont, CA: Wadsworth.

Kreber, C., \&Kanuka, H. (2006). The scholarship of teaching and learning and the online classroom. Canadian J ournal of University Continuing Education, 32(2), 109- 131. Retrieved from http:// www.extension.usask.ca/ cjuce/

Laat, M., Lally, V., Lipponen, L., \& Simons, R. 2007. Online teaching in networked learning communities: A multi-method approach to studying the role of the teacher. Instructional Science, 35(3), 257-286. doi:10.1007/ s11251-006-9007-0

Laurillard, D. (2002). Rethinking university teaching. London: Routledge Falmer. 
Le Boterf, G. (2000). Ingeniería delas competencias. Barcelona: Gestión 2000/ EPISE.

Lokken, F., \&Womer, L. (2007). Trends in e-learning: Tracking the impact of elearning in higher education. Washington, DC: Instructional Technology Council.

Mcmillan, J ., \& Schumacher, S. (2005). Investigación educativa. Madrid: Pearson Addison Wesley.

Major, C. (2010). Do virtual professors dream of electric students? College faculty experiences with online distance education. Teachers College Records, 112(8), 2154-2208.

Marcelo, C. (2006). Las nuevas competencias en e-learning: ¿qué formación necesitan los profesionales del e-learning? In J . Martínez, C. Marcelo, D. Garrido, D. Hernández, D. Puente, V. H. Perea, B. Tancredi, M. M. Lucero, W. Acosta, L. González, M. J . Gago, C. Marcelo \& M. J ordano (Eds.), Prácticas dee-learning. Churriana de la Vega (Granada): Ediciones Octaedro.

McDiarmid, G.W., \& Clevenger-Bright, M. (2008). Rethinking teacher capacity. In M. Cochran-Smith, S. Feiman-Nemser \&J . McIntyre (Eds.), Handbook of research on teacher education : Enduring questions in changing contexts (pp. 134-156). Nueva York: Routledge.

Minota, M. (2011): Reflective teaching as self-directed professional development: Building practical or work-related knowledge. In T. Bates, A. Swennen \& K. J ones (Eds.), The professional development of teacher educators. London, Routedge.

Muñoz Carril, P.C., \& González Sanmamed, M. (2009). Plataformas de teleformación y herramientas telemáticas. Barcelona: UOC.

Salmon, G. (2000). E-moderating: The key to teaching and learning online. London: Taylor \& Francis.

Salmon, G. (2004). E-Actividades: El factor clave para una formación en línea activa. Barcelona: Editorial UOC.

Sangrá, A., \&González Sanmamed, M. (2004a) (Eds.). La transformación de las universidades a través de las TIC: discursos y prácticas. Barcelona: UOC.

Sangrá, A., \& González Sanmamed, M. (2004b). El profesorado universitario y las TIC: redefinir roles y competencias. In A. Sangra \& M. González Sanmamed (Eds.), La transformación de las universidades a través de las TIC: Discursos y prácticas (pp. 73-97). Barcelona: UOC. 
Shulman, L. S. (1987). Knowledge and teaching: Foundations of the new reform. Harvard Educational Review, 57(1), 1-22.

Spector, J . M. (2007) (Ed.). Finding your onlinevoice: Stories told by experienced online educators. Mahwah, NewJ ersey: Lawrence Earlbaum Associates.

Thach, L., \& Murphy, K. (1995): Competencias for distance education professionals. Educational Technology Research and Development, 43(1), 57-79.

UNESCO (2008): Estándares de competencias en TIC para docentes. Paris: UNESCO. Retrieved from http:// portal.unesco.org/ es/ ev.phpurl_id=41553\&url_do=do topic\&url_section=201.html

Varvel, V. (2007). Master online teacher competencies. Online J ournal of Distance Learning Administration, 10(1). Retrieved from http:// www.westga.edu/\%7Edistance/ ojdla/ spring101/varvel101.pdf

Wiesenberg, F., \& Hutton, S. (1996). Teaching a graduate program using computermediated conferencing software: Distance education futures. The J ournal of Distance Education, 11(1), 83-100. Retrieved from http:// www.jofde.ca/index.php/jde/article/view/246/455

Williams, P. E. (2003). Roles and competencies for distance education programs in higher education institutions. American J ournal of Distance Education, 17(1), 45- 57. doi: 10.1207/S15389286AJ DE1701_4

Yeung, D. (2001). Quality assurance of web-based learning in distance education institutions. J ournal of Distance Learning Administration, 4(4). Retrieved from http:// www.westga.edu/ distance/ ojdla/ winter44/yeung44.html

Zabalza, M. A. (2003). Competencias didácticas del profesorado universitario. Diseño curricular en la universidad. Madrid: Narcea.

\section{Athabasca University $\mathbf{a}$}



